\title{
THE I887 SURVEY OF THE LONDON WORKING CLASS
}

For the historian of modern European society the problem of the extent and nature of unemployment at any particular time and in any particular place is a challenging and even frustrating one. It is clearly an important question to ask and yet, except for very recent times, it is almost impossible to answer satisfactorily. Where there are data they are incomplete and their reliability doubtful. This is true even of such a society as Victorian Britain, which might be thought to have a considerable amount of useful material. The early Victorian social investigators in Britain seldom dealt with the problem of unemployment, preferring to focus on educational, sanitary, and similar elements of working-class living standards. Admittedly, from the middle of the nineteenth century continuous series of unemployment figures become increasingly available relating to particular trades and from these aggregate figures have been calculated. ${ }^{1}$ But the defects of these returns, made by various trade unions and based upon the numbers receiving unemployment benefit, have been recognized almost from the time that they began to appear. As for official labour statistics in general, those for the period before 1886 have recently been described as "deficient, chaotic, and unmanageable". ${ }^{2}$ The unemployment statistics improved little after 1886. They continued to be derived from the same sources as before, though a much greater number of unions made returns. But the very nature of the returns means that they were biassed towards the unionised workers in industries like heavy engineering. The non-unionised poorest section of the working class was thus eliminated. These national figures are particularly unrepresentative of a centre such as London,

\footnotetext{
1 E.g., see B. R. Mitchell and Phyllis Deane, Abstract of British Historical Statistics (Cambridge, 1962), pp. 64-5.

2 Roger Davidson, "Llewellyn Smith, the Labour Department, and government growth 1886-1909", in: Gillian Sutherland (ed.), Studies in the growth of nineteenth century government (London, 1972), p. 279.
} 
where many of the industries covered by the returns were of little importance.

There are, however, other sources for the study of unemployment in Victorian London which have not always been as fully utilized as they might be. Much of the great survey carried out by Charles Booth and his associates at the end of the century was concerned with industrial structure. ${ }^{1}$ The second series ("Industry") of the Booth survey has too often and too easily been dismissed as a failure. In any case, the surviving manuscript notebooks may yet yield a rich harvest on certain industrial questions. ${ }^{2}$ Another major source, buried in the parliamentary papers, is the tabulation of the statements made by about 30,000 working men in four areas in London in March 1887. ${ }^{3}$ Even Gareth Stedman Jones's excellent pioneering work on the London poor does not utilize this survey to any great extent, which leaves a quantitative gap in an otherwise impressive work. ${ }^{4}$

The winter of 1886-7 was a particularly severe one for the London working class, and the survey carried out in March was the direct result of public concern. In early January a Church of England minister of Bow had written to the Times giving brief particulars of about 1,000 families out of 1,600 given relief at Christmas. The average family income was less than seven shillings a week. ${ }^{5}$ The Mansion House Committee on Metropolitan Poverty, created to relieve distress among the working class, had already tried to carry out its own survey in mid-December. ${ }^{6}$ On 20 January the Times printed a letter from a minister in Poplar seeking funds to aid those in distress. The next day a letter from H. M. Hyndman, the leader of the Social Democratic Federation, pointed out that his organisation, in its canvass of 59 streets in Marylebone, had found 1,327 adult males out of work. It is not surprising that the same day a conference was held at which a resolution was passed calling for an "exhaustive inquiry into the extent, character, and causes of the distress existing in London". ${ }^{7}$ This conference was very much the work of the philanthropic aristocracy. Lord Cowper chaired, while Lords Brownlow and Compton seem to

1 For the history of the Booth survey see T. S. and M. B. Simey, Charles Booth, Social Scientist (Oxford, 1960), passim.

2 Theses are housed in the library of the London School of Economics and Political Science.

3 Condition of the Working Classes. Report and Tabulation of Statements made by men living in certain selected districts in London in March, 1887 [Parliamentary Papers, 1887, LXXI]. Hereafter Tab. Statements.

4 Gareth Stedman Jones, Outcast London (Oxford, 1971).

- Times, 8 January 1887.

- Times, 11 January 1887, letter from W. H. Birley,

7 Hansard, Third Series, Vol. 312, cc. 532-3. 
have dominated discussion seeking the causes of distress in patterns of employment. ${ }^{1}$

The resolution was forwarded to the government which agreed to institute an inquiry in four districts (St George's-in-the-East, parts of Battersea, parts of Hackney, and parts of Deptford). The survey was taken on 19 March 1887 (a Saturday) and some 31,635 working men were interviewed, though 2,184 returns were rejected as "quite useless", mainly because the collector had failed to state whether the man was in or out of work. ${ }^{2}$ The remaining 29,451 statements were then tabulated. It is clear that the government had some difficulty in dealing with the mass of data collected. As late as August the President of the Local Government Board was forced to explain the delay in publication of the results in terms of the "very novel character" of the investigation. ${ }^{3}$ In the end the men were divided into 35 trade groups. The percentage in each group unemployed on the day of the inquiry was tabulated together with the percentage of those in work who stated that they were in regular work and the percentage unemployed at any time in the twenty week period since 31 October 1886. Moreover, the men, both those in and those out of work, were asked to state how long they had been out of work during the previous twenty weeks. These figures were then tabulated by two week divisions up to twelve weeks, those unemployed for more than twelve weeks being classified together. In addition, information was gathered on the size of families, ages, the number of rooms occupied, rents, wages, country of origin, and sources of income other than personal earnings.

It might be hoped that this large amount of information would provide an excellent basis for helping to assess the extent and concentration of unemployment in late Victorian London, But the report of William Ogle, Superintendent of Statistics at the General Register Office, baldly concludes "the returns are of very small statistical value". ${ }^{4}$ Ogle's main reason for this sweeping conclusion was that of the 8,008 men out of work on the day 5,964 stated that they had had no work for twelve weeks or more out of the previous twenty and only 1,132 stated that they had received assistance from parish, club, or charity while 2,288 stated that they had had assistance from other members of their families. Thus, according to Ogle, at least 4,588 of the men (with their families) had lived three months or more without

1 Times, 22 January 1887.

2 Tab. Statements, p. vii.

s Hansard, Third Series, Vol. 320, c. 1732.

4 Tab. Statements, p. xv. 
any kind of assistance. ${ }^{1}$ As this was deemed to be impossible the men's statements, Ogle thought, must be false. Ogle's conclusion has probably been the main influence in deterring historians from making any great use of the 1887 survey. To restore the survey to its true position as one of the most valuable carried out in the nineteenth century in Britain it is necessary to test the consistency of the working men's statements. Such a test is, of necessity, statistically orientated.

The first point to be made is that Ogle's arithmetic was incorrect. $\mathrm{He}$ arrived at the figure of 4,588 by subtracting the sum of 1,132 and $2,288(3,420)$ from 8,008 and then saying that all these were unemployed for three months or more. In fact, 4,588 of the 8,008 is the figure for those who either stated that they did not receive assistance or refused to furnish the information or for whom the information was not given for other reasons. However, 1,663 of the 8,008 unemployed stated that they had been unemployed for less than twelve weeks and 381 could not be certain about the length of their unemployment or refused to answer, totalling 2,044 who may have been unemployed for less than twelve weeks. Thus Ogle's minimum figure of 4,588 must be reduced to 2,544. Moreover, of the 5,820 men who did not positively state that they had assistance from other members of the family 1,167 gave no information as to whether or not they received such assistance. ${ }^{2}$ This reduces the minimum figure of those unemployed for twelve weeks or more who can definitely be stated to have received (or claimed that they received) no assistance from 2,544 to 1,377 . This figure should be further reduced since although 6,876 men did not state that they received assistance from parish, club, or charity, the report does not indicate how many furnished no information either way. ${ }^{3}$ The minimum figure, therefore, was more likely less than 1,000.

The actual number of men who claimed to be both unemployed for more than twelve weeks and to have received no assistance could of course be higher than the minimum figure since there would be some overlapping in all the above categories. But even this does not disprove the veracity of the men's statements. As the Rev. J. W. Lewis, a branch chairman of the Dock Labourers' Union, told the Royal Commission on Labour, the very poor would somehow manage to exist with a little help from friends or by running into debt. ${ }^{4}$ The chairman of the Paddington Board of Guardians, S. D. Fuller, argued

1 Ibid., p. iii.

2 Ibid., p. 4.

I Ibid., p. 5.

- Royal Commission on Labour, Minutes of Evidence, Group B [PP, 1892, XXXVI, Pt II], p. 129. 
that it was the pawnbrokers who knew best about the "deserving poor" who did not apply for relief, many of the poor being too proud to apply. ${ }^{1}$ Finally, when Charles Booth studied the family budgets of six very poor families over a five week period he found that expenditure exceeded income by one sixth. ${ }^{2}$ Consequently, at least the major reasons given by Ogle for rejecting the results of the survey seem to have less validity than he imagined.

To test the results more rigorously it is necessary to look for signs of internal consistency. Where there exists a large number of men answering a variety of separate questions, it seems reasonable to argue that if these answers can be shown to be consistent, then there is strong presumptive proof for the reliability of these answers when taken in the mass. In the case of this survey there is a yardstick in the percentages of men in the trade groups stated to be out of work on the day of the inquiry. It may be argued that men may lie about the regularity of their employment or the amount of time they have spent out of work, but there is a certain finality about the fact of whether or not a man is in work on a particular day.

The statements make possible one very decisive test of internal consistency. The percentage of men in each trade group in work on the day of the inquiry can be calculated, as can the percentage of those in work who stated themselves to be in regular work. From these two figures the percentage who might be out of work at any time over any considerable period, such as that from 31 October 1886 to 19 March 1887, can be predicted. This predicted figure can be compared with the percentage of men who actually claimed to have been out of work at any time in that period. The two sets of figures are given in the first two columns of Table 1 . The correlation coefficient between these predicted and actual percentages is .97. Even this very high coefficient could be brought closer to unity by the exclusion of one or two exceptional cases, most notably that of hawkers and costermongers. ${ }^{3}$ Questions concerning whether or not a man was in work and whether or not he had been out of work at any time over the previous twenty weeks probably had little meaning for a hawker. Thus one powerful test of reliability, based on internal consistency, has shown a strongly positive reaction.

1 Royal Commission on the Aged Poor. Minutes of Evidence [PP, 1895, XIV], p. 135.

${ }^{2}$ Charles Booth, Life and Labour of the People in London, 3rd ed. (London, 1902-3), Series I, Vol. I, p. 138.

${ }^{8}$ Excluding just this one group the correlation coefficient is .99. A useful introduction to simple statistical methods for historians is Roderick Floud, An Introduction to Quantitative Methods for Historians (London, 1973). 
Table 1: Unemployment in 35 trade groups in certain areas of London in the winter of $1886-7$ (in percentages)

\begin{tabular}{|c|c|c|c|c|c|}
\hline Trade group & $\begin{array}{l}\text { Predict- } \\
\text { ed out } \\
\text { of work } \\
\text { at some } \\
\text { time }\end{array}$ & $\begin{array}{c}\text { Stated } \\
\text { out of } \\
\text { work at } \\
\text { some } \\
\text { time }\end{array}$ & $\begin{array}{l}\text { Out of } \\
\text { work for } \\
\text { more } \\
\text { than } 12 \\
\text { weeks }\end{array}$ & $\begin{array}{c}\text { Average } \\
\text { number } \\
\text { out of } \\
\text { work }\end{array}$ & $\begin{array}{r}\text { Out of } \\
\text { work } \\
\text { on day } \\
\text { of } \\
\text { survey }\end{array}$ \\
\hline Clerks, travellers & 22.0 & 22.4 & 11.6 & 11.6 & 15.0 \\
\hline Carmen, carters & 33.2 & 37.7 & 18.0 & 20.4 & 17.2 \\
\hline Cabmen, etc. & 35.5 & 38.4 & 17.6 & 20.5 & 18.8 \\
\hline Servants, etc. & 39.2 & 38.8 & 22.1 & 22.6 & 24.3 \\
\hline Shopmen, etc. & 29.8 & 29.5 & 15.7 & 16.6 & 17.4 \\
\hline Bakers & 41.2 & 44.9 & 27.2 & 27.4 & 27.3 \\
\hline Butchers & 48.5 & 48.3 & 29.6 & 30.0 & 25.9 \\
\hline Tailors & 73.3 & 66.8 & 33.1 & 40.1 & 21.9 \\
\hline Bootmakers & 70.6 & 67.9 & 30.0 & 37.9 & 17.1 \\
\hline Watchmakers, etc. & 29.9 & 37.2 & 14.2 & 18.3 & 12.8 \\
\hline Machine makers, etc. & 33.7 & 34.5 & 21.7 & 21.4 & 20.5 \\
\hline Blacksmiths, etc. & 47.3 & 48.3 & 29.6 & 30.0 & 25.9 \\
\hline Printers, etc. & 27.9 & 28.6 & 11.7 & 14.7 & 11.4 \\
\hline Carpenters, etc. & 59.6 & 58.8 & 30.9 & 33.9 & 27.3 \\
\hline Coopers & 46.8 & 47.4 & 24.0 & 27.7 & 26.6 \\
\hline Shipwrights, etc. & 69.6 & 65.7 & 43.5 & 42.5 & 43.6 \\
\hline Masons, bricklayers, etc. & 77.6 & 78.7 & 46.6 & 48.8 & 36.6 \\
\hline Painters, plumbers, etc. & 72.0 & 71.5 & 46.5 & 46.3 & 33.5 \\
\hline Wheelwrights, etc. & 31.8 & 34.5 & 17.9 & 16.2 & 15.5 \\
\hline Cabinet-makers, etc. & 49.8 & 61.4 & 27.8 & 35.1 & 20.2 \\
\hline Furriers, etc. & 49.7 & 48.4 & 29.0 & 29.1 & 22.5 \\
\hline Sugar-bakers, refiners & 14.8 & 15.7 & 9.6 & 9.4 & 8.7 \\
\hline Tobacco workers & 60.0 & 55.7 & 29.5 & 34.2 & 27.4 \\
\hline Policemen & 7.8 & 8.3 & 3.9 & 4.3 & 6.1 \\
\hline Seamen, etc. & 60.3 & 54.0 & 28.2 & 31.2 & 30.5 \\
\hline $\begin{array}{l}\text { Railwaymen except } \\
\text { drivers, porters }\end{array}$ & 3.6 & 5.1 & 2.7 & 2.7 & 2.2 \\
\hline Porters & 8.3 & 9.4 & 5.0 & 5.5 & 5.8 \\
\hline Engine drivers & 23.0 & 24.7 & 13.3 & 13.9 & 13.9 \\
\hline Unskilled labourers & 62.7 & 62.2 & 39.2 & 39.7 & 36.8 \\
\hline Dockers & 88.0 & 89.4 & 56.5 & 58.4 & 54.8 \\
\hline Hawkers, costermongers & 78.6 & 59.9 & 36.0 & 36.8 & 26.0 \\
\hline Messengers, watchmen, etc. & 25.6 & 24.6 & 15.3 & 15.1 & 12.8 \\
\hline $\begin{array}{l}\text { Postmen, other govern- } \\
\text { ment service }\end{array}$ & 6.6 & 7.3 & 2.3 & 2.4 & 3.9 \\
\hline Artisans (undefined) & 41.3 & 40.5 & 21.1 & 23.5 & 17.6 \\
\hline Nondescripts & 45.4 & 41.4 & 25.3 & 25.7 & 25.5 \\
\hline Total & 52.5 & 52.3 & 30.1 & 31.9 & 27.4 \\
\hline
\end{tabular}

Source: Tab. Statements, pp. 10-127. For a full list of the occupations see pp. vii-viii. 
The second column of Table 1 gives some idea of the number of men out of work at some time in the winter of 1886-7. Many of these men may have been out of work for only very short periods and so it is useful to try to construct an index of average unemployment in the 35 trade groups. The third column of Table 1 gives the percentage of the men in each trade group who claimed to have been out of work for more than twelve weeks out of the previous twenty. The fourth column gives an index of average unemployment. ${ }^{1}$ The correlation coefficient between the average figures and those for the day of the inquiry is .89 (significant at the .001 level). The average for the winter is, as would be expected, somewhat higher than the percentage out of work on the day of the inquiry (since the worst of the winter was over), a rule which holds good for two thirds of the groups, the other third having roughly the same figures. This seasonal trend is most marked in eight cases: the two building groups (where the average was about thirteen per cent higher than the day of the inquiry), tailors, bootmakers, carpenters, cabinet-makers, tobacco workers, and hawkers and costermongers. Excluding these eight trades the correlation coefficient for the other twenty-seven between the average level of unemployment in the winter of 1886-7 (according to the men's statements) and the percentage in each trade out of work on the day of the inquiry is .98 .

This high correlation and the closeness of the two sets of figures, with a seasonal tendency generally noticeable and exaggerated in a number of trades, means that it is difficult to doubt the general reliability of the men who claimed to have been out of work for more than twelve weeks. As the third column of Table 1 shows, the average is very much dependent on these men, who might well be collectively described as a lumpenproletariat. The correlation coefficient between the third and fourth columns is .99 and in all trades the men who had been unemployed for more than twelve weeks formed a large proportion of those who were unemployed at any time. Thus unemployment was to a considerable extent concentrated in the lowest section rather than spread evenly over the whole of the working class. The average unemployment rate among those unemployed on the day of the inquiry was 70.7 per cent, compared with 17.8 per cent for those in

1 This has been calculated by assuming that those out of work for more than twelve weeks were, on average, unemployed for sixteen weeks. For example, there were 645 seamen, bargemen, and lightermen included in the returns. 297 stated that they had been in work throughout the winter, 6 that they had been unemployed for $0-2$ weeks, 19 for 2-4 weeks, 40 for 4-6 weeks, 16 for 6-8 weeks, 46 for 8-10 weeks, 27 for 10-12 weeks, and 177 for more than 12 weeks while 18 could not be certain. Thus the percentage of average unemployment was $100 \times(297 \times 0+6 \times 1+19 \times 3+40 \times 5+16 \times 7+46 \times 9+27 \times 11+177 \times 16)$ equals 
Table 2: Average unemployment in 35 trade groups during the winter of 1886-7 for those in work (A) compared with those our of work (B) on the day of the inquiry and the percentage of those out of work who claimed to have been out of work for more than twelve weeks (C)

\begin{tabular}{lrrr} 
Trade group & \multicolumn{1}{c}{$\mathrm{A}$} & $\mathrm{B}$ & $\mathrm{C}$ \\
Clerks, travellers & 3.9 & 71.6 & 80.2 \\
Carmen, carters & 11.6 & 66.5 & 72.5 \\
Cabmen, etc. & 11.2 & 63.2 & 69.5 \\
Servants, etc. & 10.0 & 63.1 & 66.7 \\
Shopmen, etc. & 7.2 & 64.2 & 67.4 \\
Bakers & 14.2 & 65.1 & 69.2 \\
Butchers & 13.8 & 66.2 & 71.0 \\
Tailors & 31.8 & 70.6 & 75.4 \\
Bootmakers & 31.0 & 71.0 & 77.0 \\
Watchmakers, etc. & 11.6 & 66.9 & 72.2 \\
Machine makers, etc. & 9.3 & 70.7 & 81.0 \\
Blacksmiths, etc. & 15.3 & 73.4 & 84.4 \\
Printers, etc. & 8.5 & 62.0 & 64.7 \\
Carpenters, etc. & 21.0 & 68.9 & 74.6 \\
Coopers & 12.6 & 71.3 & 74.4 \\
Shipwrights, etc. & 20.6 & 73.4 & 83.8 \\
Masons, bricklayers, etc. & 36.8 & 70.8 & 80.0 \\
Painters, plumbers, etc. & 33.3 & 72.3 & 82.1 \\
Wheelwrights, etc. & 10.0 & 75.2 & 90.5 \\
Cabinet-makers, etc. & 26.2 & 69.2 & 72.5 \\
Furriers, etc. & 16.1 & 75.2 & 91.3 \\
Sugar-bakers, refiners & 4.4 & 63.5 & 70.0 \\
Tobacco workers & 20.2 & 70.4 & 73.5 \\
Policemen & 1.2 & 63.9 & 75.0 \\
Seamen, etc. & 16.3 & 68.0 & 72.9 \\
Railwaymen except drivers, porters & 1.4 & 63.8 & 75.0 \\
Porters & 1.9 & 64.7 & 68.8 \\
Engine drivers & 5.8 & 69.4 & 77.3 \\
Unskilled labourers & 21.6 & 72.0 & 79.9 \\
Dockers & 36.9 & 72.3 & 78.0 \\
Hawkers, costermongers & 24.7 & 73.7 & 85.1 \\
Messengers, watchmen, etc. & 7.3 & 67.9 & 78.9 \\
Postmen, other government service & 0.8 & 80.0 & 100.0 \\
Artisans (undefined) & 13.7 & 70.8 & 79.8 \\
Nondescripts & 11.0 & 69.7 & 73.0 \\
& & & \\
Total & 17.8 & 70.7 & 78.2 \\
& & &
\end{tabular}

work on the day. ${ }^{1}$ The variations in this general tendency are shown in Table 2 .

In none of the 35 trade groups did the average unemployment rate for those out of work on the day of the inquiry fall below 60 per cent.

1 From Tab. Statements, p. 4. 
The maximum figure that can be reached in the second column of Table 2 is 80 per cent since in constructing this "average" figure it was assumed that those who put themselves down as having been out of work for more than twelve weeks were, on average, unemployed for sixteen weeks. The third column of Table 2 , the percentage of those unemployed who stated that they had been unemployed for more than twelve weeks, therefore gives a better indication of the importance of the lumpenproletariat. In no group does this proportion drop below two-thirds, the proportion for all groups being nearly four-fifths. However, the group still vary considerably as to how far they can be divided into a regularly employed majority and a casually employed minority.

At the bottom were eleven groups: tailors, bootmakers, carpenters, shipwrights, masons, painters, cabinet-makers, tobacco workers, unskilled labourers, dockers, and hawkers. Within this set of trades there was a clear distinction between those which were highly seasonal and which were not usually thought of as poor occupations (that is trades which would appear in a different light if the survey had been taken at the end of summer) and those which were perpetually irregular and comprised the poorest sections of the population. But in both types in the winter of 1886-7 the majority were out of work at some time and average unemployment for those out of work was less than four times that of those in work on 19 March. Then comes a miscellaneous collection of eleven trades in which this last ratio rises to between four and seven: carmen, cabmen, servants, bakers, butchers, watchmakers, blacksmiths, coopers, furriers, seamen, and the undefined artisans. In these trades roughly half to two thirds of the men had been employed throughout the winter of 1886-7. Thirdly, there was a set of five trades in which the distinction between casuals and regulars was very clearly marked: shopmen, machine makers, printers, wheelwrights, and messengers and watchmen (and also the "nondescripts"). Here two-thirds to three-quarters had remained in continuous employment while the rest in appalling symmetry had been unemployed for two-thirds to three-quarters of the time. Finally, there were the low unemployment trades - white collar workers, government service, and the railways - in which those in work on 19 March had suffered less than one-tenth of the unemployment of those out of work, with three-quarters or more of the men being in continuous employment throughout the winter. ${ }^{1}$

1 The sugar bakers are also in this category. Although a declining industry the refineries worked to a very regular pattern throughout the year. The confectioners had a long busy season from October to July and a fairly short but very intense slack season in late summer and early autumn. 
Clearly the above figures are likely to give too black a picture of the extent and concentration of unemployment in normal times. The survey concentrated on working men and middle class groups had as far as possible been excluded. It appears that about two-thirds of the population of St George's-in-the-East was considered and presumably many of the remaining one-third were the more affluent inhabitants. On the other hand, two of the poorest groups - the aged and widows were excluded from the survey. Secondly, winter was always likely to be a period of high unemployment. Again, however, this must be qualified. Many trades had their busiest season in the winter, from confectioners to undertakers, so that we must be careful of too readily assuming that the position in summer was overall very much better, especially outside the building and related trades. ${ }^{1}$

The most serious difficulty in interpreting the data is the very reason they were collected in the first place - the winter of 1886-7 was a cyclical peak of unemployment, not just a seasonal one. That winter saw "serious distress among the poor of London" because of a "great trade depression". ${ }^{2}$ But the importance of this fact could also be overemphasized. Little improvement occurred during 1887 in London and the winter of $1887-8$ was nearly as bad as the previous one. ${ }^{3}$ In any case, cyclical fluctuations were perhaps not as large in London as they were in the country as a whole. The Mitchell-Deane index of national unemployment is greatly influenced by the high fluctuations in the engineering, metal, and shipbuilding unions. But carpenters and joiners, woodworkers and furnishers, and printers and binders did not suffer such high fluctuations. ${ }^{4}$ The returns from these unions are probably a better indication of cyclical variations in London than returns from the heavy engineering industries which were of little importance in late nineteenth century London. Even so, it is apparent that it would be difficult to gain from the 1887 survey a reliable picture of unemployment among the whole population of London in an average year (if such a thing exists). In this sense the value of the survey is that it gives a much more detailed impression of part of a picture which on the whole is still visible only in outline.

The usefulness of the survey is not confined to the data it generates on unemployment. It also contains perhaps the most complete set of wages, rents, and size of accommodation statistics available for the

1 For a general discussion of the problem of seasonality see Stedman Jones, op. cit., pp. 33-51.

2 Margaret A. Tillard and Charles Booth, Life and Labour, Series I, Vol. I, p. 230.

Ibid., p. 231.

4 B. R. Mitchell and Phyllis Deane, op. cit., pp. 64-5. 
London working class in the period. It is very difficult to check the reliability of the figures - it is quickly apparent that they are broadly consistent with the information given in the Booth survey and the 1891 census but rigorous testing is out of the question. For this reason what follows must be considered in the nature of a speculative exercise to see whether the survey can be considered to be of any help in solving one of the most difficult but interesting problems of late Victorian history, the nature of the relationship between poverty, unemployment, and low wages.

The data for this speculative exercise is given in Table 3 . The first column gives the median earnings for those who responded to this question. Since the men were asked to state not their income but their normal weekly earnings when in work it is instructive to compare the overall figure and the figures for each group with those given just by the men out of work (see the second column). Where there were less than fifty men in the last category the figure was omitted. However, the general closeness of the two estimates tends to give some degree of confidence in their accuracy, particularly in terms of answering the question asked. The third column gives the proportion of those who responded who stated that when in full work they earned less than 21 shillings a week. Since the non-response rate on the income question was unusually high compared with the others (eighteen per cent), the fourth column was included, which shows the percentage of all workers in each trade group who stated that they earned less than 21 shillings when in work.

The fifth column gives a crude standard of living index deduced from the available information. The men were asked to state how many rooms they and their families lived in. While these answers must be treated with caution because of the usual problem of the definition of "room" it seems reasonable to take the answers in the bulk as a valid index of accommodation. ${ }^{1}$ But this did not seem to be a satisfactory index of the standard of living. In an occupation with many young or old men living in limited accommodation this would underestimate their standard of living, while in an occupation with many men in middle life with children to house it would exaggerate it. Equally, the alternative of the average amount of rent paid (the sixth column) could be misleading if more rent was being paid merely to buy essential space. The index used consists of dividing the average rent in each trade group by the number of persons per room. Thus as rent increases and number of persons per room declines the index increases.

1 In any case, too much may be made of these objections: a large proportion of the Victorian working class did not have to worry about the complications of separate kitchens, bathrooms, or lavatories. 
Table 3: Wages, rents, and accommodation standards in 35 trade groups in London in March 1887

\begin{tabular}{|c|c|c|c|c|c|c|}
\hline Trade group & $\begin{array}{c}\text { Median } \\
\text { Wages } \\
\text { (all) }\end{array}$ & $\begin{array}{l}\text { Median } \\
\text { Wages } \\
\text { (Unem- } \\
\text { ployed) }\end{array}$ & $\begin{array}{c}\text { Low } \\
\text { Wages } \\
\text { (1) }\end{array}$ & $\begin{array}{c}\text { Low } \\
\text { Wages } \\
\text { (2) }\end{array}$ & $\begin{array}{l}\text { Stand- } \\
\text { ard of } \\
\text { Living }\end{array}$ & $\begin{array}{l}\text { Average } \\
\text { Rent }\end{array}$ \\
\hline Clerks, travellers & 35.1 & 30.7 & 22.0 & 13.3 & 50.9 & 6.8 \\
\hline Carmen, carters & 21.8 & 21.4 & 42.4 & 37.1 & 31.0 & 5.1 \\
\hline Cabmen, etc. & 23.4 & 22.4 & 32.5 & 25.7 & 35.4 & 5.5 \\
\hline Servants, etc. & 21.1 & 20.0 & 49.8 & 37.1 & 40.3 & 5.9 \\
\hline Shopmen, etc. & 25.3 & 21.5 & 34.4 & 24.1 & 43.8 & 6.3 \\
\hline Bakers & 24.9 & 22.7 & 29.6 & 25.0 & 34.0 & 5.5 \\
\hline Butchers & 24.7 & 25.3 & 39.6 & 30.3 & 38.2 & 5.7 \\
\hline Tailors & 21.7 & 30.0 & 48.7 & 39.7 & 36.9 & 6.3 \\
\hline Bootmakers & 20.2 & 21.9 & 56.7 & 46.6 & 34.2 & 5.7 \\
\hline Watchmakers, etc. & 34.0 & - & 21.2 & 14.1 & 42.5 & 6.6 \\
\hline Machine makers, etc. & 41.8 & 39.7 & 11.2 & 8.8 & 41.1 & 6.3 \\
\hline Blacksmiths, etc. & 35.7 & 36.4 & 14.8 & 11.9 & 37.6 & 5.8 \\
\hline Printers, etc. & 36.0 & 32.0 & 19.9 & 15.0 & 47.3 & 6.4 \\
\hline Carpenters, etc. & 38.6 & 39.9 & 13.3 & 11.0 & 41.9 & 6.3 \\
\hline Coopers & 27.9 & - & 28.1 & 22.5 & 35.2 & 5.8 \\
\hline Shipwrights, etc. & 39.8 & 42.6 & 10.5 & 7.8 & 41.9 & 6.1 \\
\hline Masons, bricklayers, etc. & 39.3 & 39.5 & 12.9 & 10.6 & 31.4 & 5.8 \\
\hline Painters, plumbers, etc. & 32.5 & 35.5 & 18.1 & 14.7 & 38.5 & 5.8 \\
\hline Wheelwrights, etc. & 36.7 & - & 14.3 & 9.9 & 49.7 & 6.4 \\
\hline Cabinet-makers, etc. & 25.9 & 28.6 & 39.9 & 30.5 & 37.8 & 6.1 \\
\hline Furriers, etc. & 22.9 & - & 41.8 & 34.7 & 32.2 & 5.4 \\
\hline Sugar-bakers, refiners & 22.3 & - & 36.4 & 31.3 & 33.5 & 5.5 \\
\hline Tobacco workers & 20.7 & - & 53.4 & 44.4 & 32.4 & 5.8 \\
\hline Policemen & 28.7 & - & 6.8 & 5.5 & 53.0 & 6.8 \\
\hline Seamen, etc. & 24.9 & 23.2 & 38.8 & 30.7 & 36.4 & 5.5 \\
\hline Railwaymen, except & & & & & & \\
\hline drivers, porters & 23.6 & - & 21.2 & 17.3 & 51.0 & 6.5 \\
\hline Porters & 19.5 & - & 65.0 & 59.4 & 43.1 & 5.8 \\
\hline Engine divers & 28.5 & 27.4 & 12.1 & 10.1 & 42.3 & 6.1 \\
\hline Unskilled labourers & 20.9 & 21.0 & 51.5 & 45.3 & 27.1 & 4.7 \\
\hline Dockers & 19.8 & 20.5 & 70.6 & 65.7 & 17.1 & 3.7 \\
\hline Hawkers, costermongers & 15.8 & - & 79.6 & 53.9 & 23.8 & 4.5 \\
\hline $\begin{array}{l}\text { Messengers, watchmen, } \\
\text { etc. }\end{array}$ & 23.2 & - & 33.3 & 25.6 & 46.2 & 6.3 \\
\hline $\begin{array}{l}\text { Postmen, other gov. } \\
\text { service }\end{array}$ & 24.4 & - & 43.7 & 29.6 & 50.8 & 6.7 \\
\hline Artisans (undefined) & 24.2 & 24.4 & 38.0 & 29.6 & 39.6 & 5.9 \\
\hline Nondescripts & 23.0 & 23.5 & 43.2 & 28.8 & 36.5 & 5.6 \\
\hline Total & 23.6 & 23.4 & 38.9 & 31.7 & 34.4 & 5.6 \\
\hline Response rate (per cent) & 80.0 & 86.0 & 81.7 & n.a. & n.a. & 96.8 \\
\hline
\end{tabular}


Table 4: Correlations between various indices of wages, unemployment, and standard of living (by trade groups)

$\begin{array}{ccccc}\begin{array}{c}\text { Unemployed } \\ \text { on day }\end{array} & \begin{array}{c}\text { Low } \\ \text { Wages } \\ (1)\end{array} & \begin{array}{c}\text { Low } \\ \text { Wages } \\ (2)\end{array} & \begin{array}{c}\text { Median } \\ \text { Wages }\end{array} & \begin{array}{c}\text { Standard } \\ \text { of living }\end{array} \\ .89 & .25 & .28 & .02 & -.74 \\ & .11 & .21 & -.13 & -.70 \\ & & .99 & -.85 & -.60 \\ & & & -.83 & -.64 \\ & & & & .43\end{array}$

Significant values: .05 level, .35; .01 level, .46;.001 level, .58

A high rent accompanied by overcrowding (as in many central city areas) will not, and should not, show up as a high standard of living. The results of comparing some of these indices are shown in Table 4.

Obviously it is difficult to interpret these correlations. One of the most important facts to emerge is the lack of any clear relationship between low wages and unemployment. On the basis of this evidence industries with excess unemployment were not necessarily those which paid low wages. However, both low wages and unemployment are significantly related to the standard of living index, with the latter clearly having the higher correlation. Together, whichever indices are used, low wages and unemployment explain about 75 per cent of the variation in the standard of living index. It is something of a leap of faith to move from there to argue that the 1887 survey supports the hypothesis that low wages and unemployment were largely independent causes of poverty with unemployment the more important of the two. Certainly the data suggests the common sense conclusion that where both factors operated - as in the case of dockers, unskilled labourers, and hawkers and costermongers - then the standard of living was very markedly below the average. But it also suggests that low and fairly low wages by the standards of late Victorian London could be more than compensated for by a very high regularity of employment, the best example being the various railway groups. The nature of the relationship between poverty, unemployment and low wages in Victorian Britain needs a great deal of further study, both local and national in scope, but at least the neglected 1887 survey may be considered to be productive of fruitful hypotheses as well as much useful information. 